\title{
O ENCONTRO DE PESSOAS CEGAS E NÃO CEGAS PELAS RUAS DO RECIFE
}

\author{
Sandra Simone Moraes de Araújo ${ }^{1}$
}

\section{Introdução}

Este artigo tem com objetivo mostrar como as pessoas cegas vivenciam o cotidiano nas ruas da cidade do Recife, evidenciando o encontro com o outro não cego. A pesquisa foi realizada por meio da convivência com pessoas cegas acompanhando-as pelas ruas da cidade, locais de trabalho e associações que defendem o direito deste público. O itinerário da pesquisa envolveu a investigação bibliográfica e também dialogou com o empírico, por meio da observação direta das relações que se estabelecem no cotidiano. Foi um processo de entrecruzamento do que se ler com o que se vivencia, de idas e vindas. De acordo com Marc Augé (1999), no contexto de uma pesquisa falar de "itinerário significa falar de partida, da estadia e do retorno, mesmo que se deva entender que houve várias partidas (...) e que o retorno nunca foi definitivo" (Augé, 1999: 12).

É neste caráter dinâmico que compreendo o trabalho de campo. Ele não começa quando chegamos ao lugar aonde se desenvolverá o contato com os interlocutores de pesquisa, e nem termina quando vamos embora, não percebo a pesquisa como uma linearidade em que há o momento da leitura, de entrar e sair do campo, e o momento seguinte iniciar a escrita; esses instantes se retroalimentam.

Nesta pesquisa a cidade do Recife $^{2}$ se constituiu como lócus privilegiado para a realização do trabalho de campo, embora essa cidade seja um lugar conhecido porque nela nasci e resido, é ao mesmo tempo estranho quando reconheço que ela se constitui de múltiplas cidades; verdadeiros fragmentos que se compõem a partir das relações dos diferentes grupos que nela convivem. São nesses fragmentos que destaco a alteridade, e concordo com Lévi-Strauss quando afirma: "enquanto as maneiras de ser ou de agir de certos homens forem problemas para outros homens, haverá lugar para uma reflexão

\footnotetext{
${ }^{1}$ Universidade de Pernambuco, Brasil.

${ }^{2}$ Segundo dados do censo de 2010 realizado pelo Instituto Brasileiro de Geografia e Estatística - IBGE são 147.001 pessoas com deficiência visual residentes nesta cidade, correspondendo a 10,33\% da sua população. Mas é importante salientar que devido ao fato do Recife ser a capital do Estado e oferecer maior diversidade de serviços, recebe pessoas provenientes da Região Metropolitana e do Interior, o que amplia a quantidade de portadores de deficiência que transitam pelas ruas da cidade.
} 
sobre essas diferenças, que, de forma sempre renovada, continuará a ser da antropologia.” (Lévi-Strauss apud Oliveira, 1998: 55).

Compreender a diferença enquanto foco da pesquisa antropológica promove o deslocamento do olhar do plano do objeto concreto para o plano da modalidade de conhecimento, ou seja, transporta-se para um plano epistemológico. Assim, não são as aldeias longínquas, ou simplesmente o exotismo que constituem tal foco, e sim, as questões que promovem a diferença, não importa se esta diferença se manifeste próxima ou distante.

A aproximação com os sujeitos de pesquisa teve início a partir da convivência com pessoas cegas no ambiente de trabalho que além de participarem como sujeitos pesquisados, também foram interlocutores apresentando-me a amigos e parentes com deficiência visual. Além de entrar em contato com pessoas cegas também iniciei um percurso educativo para aprender um pouco mais sobre a cegueira, por isso durante seis meses fui aluna do curso de tiflologia, uma formação, cujo conteúdo comtempla o aprendizado do Braille, Orientação e Mobilidade (OM), Estimulação Essencial, Introdução a Audiodescrição, Informática e o Ensino da Matemática para pessoas cegas.

Não desmerecendo a importância das disciplinas ministradas no curso, mas quero destacar um pequeno comentário sobre orientação e mobilidade, uma técnica desenvolvida nos Estados Unidos no final da segunda guerra mundial, com o propósito de atender as necessidades de soldados que perderam a visão durante o conflito. No Brasil essa técnica começou a ser estudada em 1955, quatro anos mais tarde foi iniciado o primeiro curso para treinamento de instrutores de O.M. Mesmo com tantos anos de história e sendo uma importante contribuição para a autonomia da pessoa cega, em Recife poucos são os profissionais habilitados nas instituições que desenvolvem este trabalho, o que obriga muitos deficientes visuais a ficarem em fila de espera.

O conteúdo vivenciado durante essa disciplina foi direcionado para a prática em conduzir e ensinar pessoas com deficiência visual a desenvolver sua autonomia de locomoção em locais públicos (internos como auditórios, edifícios, centro de compras; e externos como ruas, transporte particular ou coletivo). Nesse processo de aprendizado todos os alunos foram convidados a se locomover sem o uso da visão. Começamos com a prática de caminhar, ora sendo guia, ora tendo os olhos vendados. Sentimentos múltiplos afloraram nesta prática. A princípio percebi o quanto é difícil abandonar a visão e se orientar pelos outros sentidos, tive a impressão de estar caminhando no vazio; 
mesmo orientada por outra pessoa, o medo de cair ou de me acidentar, me acompanhou durante o exercício.

Foram momentos de vertigens, que me permitiram um contato mais próximo com o universo do Outro, com a pretensão de conhecer seus mistérios, sua ordem, seu caos. Penso que uma vivência desse tipo possibilita a mudança na compreensão daquilo que está a nossa volta, favorecendo múltiplas maneiras de reconhecer um lugar, neste caso o Recife. Pedro Cezar Lopes afirma que "cada experiência de olhar é um limite, a gente não conhece as coisas como elas são. Elas são mediadas pela nossa experiência. ${ }^{3}$ " Por isso que não bastou apenas observar o campo e realizar entrevistas, necessitei apreender os saberes e fazeres desse Outro que convive no Recife, uma cidade não diferente de outra urbe, onde as relações do cotidiano, na sua maioria, são mediadas pela primazia da visão, e pouco oferece uma condição diferenciada aos cegos que a praticam. Assim, convido o leitor, para embarcar na aventura de conhecer o Recife no encontro entre pessoas cegas e não cegas, tendo como nossos guias Mauro, Pedro, Álvaro, Elza, Gilda, Ruth e Lidiane ${ }^{4}$, pessoas cegas que experimentam e vivenciam suas aventuras no contexto do Recife, informando sobre o cotidiano desse lugar, descrevendo itinerários, relações com as pessoas e as estratégias utilizadas para subverter situações que dificultam sua vivência na cidade.

\section{Praticantes da Cidade - o encontro com o outro.}

Em Cloé, cidade grande, as pessoas que passam pelas ruas não se reconhecem. Quando se veem, imaginam mil coisas a respeito umas das outras. (Calvino, 1990: 51)

Ao caminhar pelo Recife, principalmente pelo Centro da Cidade não é difícil perceber suas ruas tomadas por inúmeras pessoas se movimentando em diferentes direções, com passos apressados tentando, com o ritmo acelerado do andar, vencer o tempo. Às vezes a pressa é tão grande que esbarram uns nos outros, e xingamentos se espalham e se integram ao som da cidade. No movimento dos transeuntes apressados além da preocupação com o tempo, geralmente andam com certa desconfiança,

\footnotetext{
${ }^{3}$ Em depoimento ao documentário Janela da Alma. Direção João Jardim e Walter Carvalho. Europa Filmes. Ano 2002, 73 minutos.

${ }^{4}$ Como compromissou ético utilizamos neste artigo pseudônimos para resguardar a identidade dos entrevistados.
} 
segurando com cuidado seus pertences - bolsas, sacolas, pacotes - diante da violência urbana, visto que uma de suas facetas se expressa nos furtos e roubos que ocorrem na efervescência da urbe.

A cidade é uma mistura de história, influências externas e desejos. Seus habitantes a fazem ser o que é, constrói a identidade do lugar, dão ritmo a vida, edificam seus labirintos, escondem seus mistérios. "A cidade não se revela em todos seus segredos, por mais atento que seja o olhar de quem a observa" (Rezende, 2001: 11).

Assim, as relações entre os seus habitantes ao dividirem o espaço da cidade também revelam um pouco da sua identidade. Para as pessoas cegas que vivem no Recife, o encontro com o outro não cego às vezes acontece de maneira conflituosa, às vezes harmoniosas. De acordo com Álvaro:

Não é o fato de ser cego que tira a qualidade de vida, é o ambiente onde a pessoa vive. A vida se torna mais ou menos ruim de acordo com o ambiente onde você vive. Para incrementar essa magnitude que o Recife tem, essa beleza, eu acho que se as pessoas fossem mais solidárias, oferecessem para nós um jeito melhor de viver em Recife, completaria o que de bom que ela tem.

Gostaria que as pessoas fossem mais solidárias, porque é uma questão de educação. Têm pessoas que pegam a gente e sai puxando pelo braço. É uma questão de conscientização, e eu acho que isso ai deveria ficar a cargo das entidades que se diz nos representar. Porque o que acontece é por falta de informação. Teve certa vez que um rapaz foi me ajudar a atravessar a rua e pegou a minha mão e colocou no ombro dele e disse: eu vi na televisão que é assim, que o certo é assim. Quer dizer, o que falta nas pessoas é a informação é a educação.

O desconhecimento das pessoas de como auxiliar uma pessoa cega diante dos obstáculos das ruas também é apontado por Gilda;

\begin{abstract}
Nós encontramos bastante gente solidária, mas também tem ocasião que a gente encontra aquelas pessoas que não são solidárias, que falam assim: vou lhe ajudar. Aí quer pegar no braço, mas eu digo: Não! Se você quer me ajudar, deixe eu pegar aqui (no antebraço) ou no seu ombro. Então quando a pessoa se recusa eu digo: Então você não pode me ajuda. Porque se eu deixo ele me pegar pelo braço, lá na frente aquela pessoa pode deixar você de frente para o trânsito como aconteceu comigo duas vezes. Uma vez a cidadã me deixou no meio da Av. Agamenon Magalhães. Passou uma faixa e quando chegou na segunda ela me deixou, ela se assombrou porque o sinal abriu e correu e me deixou. É por isso que não deixo ninguém me pegar pela mão. Para ajudar um deficiente visual deve-se deixar ele pegar no braço da pessoa ou no ombro.
\end{abstract}

Na opinião de Mauro o pouco conhecimento demonstrado pela população vai além do trato com a pessoa com deficiência, é algo que abrange os diferentes grupos que praticam a cidade 
A primeira coisa eu atribuo ao descaso governamental porque se o governo tivesse uma preocupação de fato com as pessoas, então já teria feito muitas campanhas de informação, de como você lidar com a diversidade e não falo só da deficiência, é o caso do negro, é o caso da mulher, é o caso do idoso, é o caso da própria criança. Não existem campanhas na mídia, nem por parte do governo, nem por parte das grandes redes de comunicação. Campanhas centradas no humano, centrada na pessoa. Como não tem campanha não tem conhecimento, a população simplesmente desconhece essas coisas.

Ouvi poucas narrativas de normovisuais sobre o encontro com pessoas cegas, mas geralmente confirmam o que Gilda, Álvaro e Mauro observam; a falta de conhecimento. Antes de escutar e conviver com maior proximidade com os interlocutores de pesquisa, como muitos outros não cegos, também desconhecia a maneira correta de auxiliar um deficiente visual atravessar uma rua ou avenida ou desviar de um obstáculo. Não sabia que não é preciso segurá-lo, mas o contrário, oferecer o ombro ou o antebraço. Da mesma forma não era capaz de identificar o piso tátil e a importância do áudio no metrô e em elevadores.

Esse desconhecimento talvez seja efeito das artimanhas da nossa cultura, na qual se constitui como um mosaico de estilos de vida. Observar o cotidiano do Recife é perceber o entrecruzamento de múltiplas expressões do humano, suas diferentes formas de ser e se agrupar, por meio de características que envolvem aspectos: étnicos, políticos, religiosos, ou tantas outras maneiras que levam os indivíduos a se reconhecerem e se identificarem em grupos distintos.

São diversas as denominações: neotribalismo, vibe, dentre outros, muda-se as nomenclaturas, mas o sentido continua: a sociabilidade, o desejo do encontro e a constituição de laços afetivos. Numa cidade como Recife, se encontram tantos modos de vida, que mesmo praticando seu cotidiano, não somos capazes de conhecer o todo. Olhamos, mas não enxergamos isto porque nosso campo de conhecimento é sempre limitado.

A cidade é, sobretudo, "uma invenção humana, resultado de inúmeras aventuras, territórios das múltiplas travessias da cultura" (Rezende, 2007: 11). É o homem no exercício de práxis que a faz ser o que é. Por meio da sua arquitetura a cidade também revela a história de seus habitantes, sua cultura. Vitor Hugo considera a arquitetura um livro de pedra escrito através do tempo que "começou como qualquer escrita. Foi o primeiro alfabeto. Erguia-se uma pedra ao alto, e era uma letra, e cada letra era um hieróglifo e sobre cada hieróglifo repousava um grupo de ideias". (Hugo, 2007: 168). 
Qualquer transeunte ao caminhar pelo Recife, e quem sabe praticar a flanêlaria, está passivo de perceber que a organização do espaço público é pouco inclusivo. A arquitetura da cidade oferece condições reduzidas de mobilidade, em suas ruas pouco se inscrevem o cuidado com a acessibilidade seja da pessoa com deficiência, do idoso, ou qualquer outro transeunte que necessite de cuidado diferenciado. Nas poucas transformações realizadas no espaço público que vão de encontro à boa acessibilidade, ainda se encontram atitudes tais como: carros estacionados em frente as rampas destinadas a facilitar o acesso de cadeirantes; piso tátil construído com pouca observação não desviando de obstáculos (árvores, telefones públicos).

Essas inscrições visíveis no espaço da cidade mostram o pouco cuidado com as pessoas com deficiência. Tal desinteresse talvez seja o reflexo de antigos preconceitos, os quais consideram que a pessoa com necessidades especiais não podem ter um vida independente ou ainda antigos hábitos resultantes do modelo de socialização que dividia a população entre normais e não normais, destinando os segundos a abrigos, centros especializados, e esse afastamento tenha provocado o desconhecimento de como lidar com a diferença.

Mauro, Álvaro, e Gilda chamam a atenção para a ausência de campanhas que informem sobre as necessidades da pessoa com deficiência no Recife. Ações mínimas, mas que chamassem a atenção dos transeuntes, a exemplo do que se encontra em algumas ruas ou avenidas da cidade de São Paulo, próximas a instituições que atendem deficientes visuais. Placas são dispostas informando que naquela área há, com maior frequência, travessia de pessoas cegas. Em algumas paradas de ônibus e estações do metrô há banners que advertem a população sobre a prioridade de acesso de idosos, pessoas com mobilidade reduzida, gestante ou com criança no colo. São iniciativas acanhadas, mas de uso efetivo.

Entretanto, a luta iniciada no final da década de 80 do século XX com o propósito de reverter o modelo de atendimento a pessoa com deficiência forjado na ideia da segregação, continua vigente na contemporaneidade, sob a égide do discurso da inclusão, afirmando que não é a pessoa com deficiência que deve se adaptar aos parâmetros da sociedade, mas o contrário é a sociedade que deve promover a boa acessibilidade nas vias públicas, meios de comunicação, educação, esporte, lazer, mercado de trabalho, transporte, etc. 
Essas mudanças contribuem para a transformação do imaginário sobre a deficiência e exigem diversas modificações que abrangem as relações entre os indivíduos quer sejam eles deficientes ou não, alterando conceitos, atendimentos institucionais e as estruturas físicas de espaços públicos e privados de maneira a incluir as diferentes necessidades apresentadas pela população que pratica a cidade.

Ao descrever a cidade de Marília, Ítalo Calvino (1997) observa que há sempre duas Marílias que se pode visitar, do mesmo modo é o Recife, o que se transforma e o que resiste, ambos se inscrevem nos itinerários e nas pessoas que praticam a urbe. Atualmente vivemos no entrecruzamento do novo e do antigo, por isso que Mauro identifica alguns espaços de acessibilidade na paisagem e nos serviços oferecidos no Recife. Ademais, se presencia um paradoxo, ou seja, ao mesmo tempo em que há certo desconhecimento da maioria dos normovisuais sobre como lidar com uma pessoa cega para auxiliá-lo na travessia de uma rua, ou outra necessidade, há também o preceito da individualidade, da pessoa cega querer praticar a cidade da maneira que melhor the convém. Como observa Lídia:

As pessoas querem ajudar, mas elas não entendem o que é melhor. O que é melhor para você, às vezes não é o melhor para mim, e quando a gente não cede ao que ela quer, ela pensa que a gente não quer ajuda deles, é porque o que você está pensando que para mim é bom, não é?

E Pedro acrescenta:

As pessoas da cidade, graças a Deus eu não tenho de que reclamar não, elas sempre me ajudam e ajudam colegas meus, não é? Na travessia de uma rua. Muitas delas nos deixam onde a gente precisa ir, e também é bom ressaltar que as pessoas têm medo de ajudar porque não sabem se nós queremos ou não ajuda.

O espírito da urbe é forjado no encontro com o outro, numa polifonia de ideias que emergem das vinculações entre seus habitantes. Esse cenário de junção de pessoas de diferentes desejo e necessidades é passível de interações harmônicas, discordantes e violentas. Georg Simmel (1987) argumenta que na metrópole as relações entre indivíduos ou grupos são marcadas tanto por laços afetivos quanto por certo grau de impessoalidade, ou seja, "trabalha-se com o homem como se trabalha com um número, como um elemento que é em si mesmo indiferente. (Simmel, 1987: 13). 
No universo do capital marcado pelo lucro e pelo consumismo, a cidade enquanto espaço privilegiado das relações econômicas é também palco da coisificação do humano, da atitude blasé, da fragilização da solidariedade e dos vínculos afetivos. Esse retrato da contemporaneidade me faz lembrar o que Bauman (2009) considera ser uma vida líquida, na qual a maioria das realizações individuais pouco se solidifica em poses permanentes, porque a velocidade da mudança tanto das mercadorias quanto das relações entre indivíduos se tornam obsoletas em curto prazo. Mas essa rapidez não é uma característica do nosso tempo, importamos de épocas anteriores. No Recife, por exemplo, nos anos 20 do século XX a chegada dos veículos automotores impôs novo ritmo a vida de seus moradores.

Comenta Eduardo Duarte (2000) que até 1914 do referido século os habitantes dessa cidade eram servidos pelos bondes de burros que faziam o transporte de passageiros do centro ao subúrbio, havia outros que carregavam capim e outras necessidades, e também os que prestavam socorro. De cem em cem metros se encontrava uma estribaria onde ocorria à troca dos animais caso parecessem cansados. Existia também as maxambombas um veículo constituído por uma pequena locomotiva que puxava dois ou três vagões. Mas o ritmo do transporte começa a acelerar com a substituição dos bondes de burros e das maxambombas pelos bondes elétricos e mais tarde as ruas da cidade é tomada por veículos automotores, assim o tempo de locomoção cada vez mais é diminuído "permitindo que a vida fosse preenchida por mais atividades" (Duarte, 2000: 41).

No Recife de nossos dias são tantos os automóveis que em horários de movimentação intensa preenchem várias ruas e avenidas causando infinitos congestionamentos. Se antes os veículos encurtavam o tempo de locomoção e as pessoas acrescentavam mais afazeres as suas vidas, hoje o intenso trânsito são fatores de estresse, correria, impaciência, etc. E atitudes pouco solidárias tornam-se corriqueiras. Pedro observa que alguns motoristas de ônibus

não têm muito preparo, eu diria; às vezes saem de casa mau humorados e tratam mau as pessoas com deficiência, muitas vezes não nos deixa em lugares que é para deixar, deixa em lugares errados, e a gente tem que andar de pé um bom tempo, bons quarteirões nas ruas. É assim.

Pelas ruas e avenidas da cidade é comum presenciarmos certa impaciência não só de motoristas de ônibus, mas também dos condutores de veículos de passeio, 
motociclistas, e quaisquer transeuntes. Pedro considera que "a correria das pessoas quando andam na cidade é tanta que as vezes elas não percebem. Às vezes estamos caminhando e as pessoas nem percebem que eu sou cego".

E Lídia acrescenta:

penso na violência, que vem das pessoas, elas andam tão agoniadas que batem em você, bate na bengala que às vezes até quebra, passa por você como um bicho brabo. A cidade estressa. E o que é ruim para todo mundo é esses engarrafamentos, esse trânsito louco também.

$\mathrm{Na}$ efervescência do Recife, nas idas e vindas, com passos apressados muitas pessoas se movimentam em silêncio, e por vezes, o trânsito de indivíduos pela cidade se caracteriza numa multidão de solitários, em que dividem o mesmo espaço, mas um concentrado em si mesmo. E isto ocorre tanto com normovisuais ou com pessoas cegas, a individualidade, indiferença são sentimentos que abrangem a todos os humanos.

Como qualquer cidade grande, o cotidiano do Recife também é marcado pela desconfiança e medo que aflige sua população. Diariamente as páginas dos jornais ou programa televisivos, de cunho jornalístico, noticiam a criminalidade. Assaltos, furtos, assassinatos, tráfico de drogas, etc, muitas vezes são tratados com doses sensacionalistas, instaurando sentimentos de insegurança que invadem todos os cantos da urbe. Argumenta Calvino (1997) que em uma cidade é possível encontrar muitas outras, assim, o Recife também se assemelha a Perínzia lugar que escondem em seus porões os monstros de três cabeças ou seis pernas que emanam gritos guturais e assustam seus moradores. No Recife não é diferente os monstros fazem parte do imaginário da cidade e se escondem entre os habitantes, espreitam e esperam o momento para se revelar. Gilda considera como um desses seres ameaçadores as

pessoas que tratam a gente mal, pessoas que vai ajudar a gente e deixa até a gente no meio do trânsito isso aí é uma pessoa que é monstruosa, sem coração. Outro dia o Motorista do ônibus de Jardim São Pedro pediu para o moço que desceu na mesma parada me ajudar, só que ele me levou para o lado contrário, e eu fui andando e percebi que estava chegando na Igreja da Soledade e eu disse: o senhor está me levando para o lado contrário. Ele tentou me tapiá, aí eu entrei em pânico e uma moça viu e me perguntou para onde eu ia, eu disse que ia para Clínica Altino Ventura e ele me carregou ao contrário, aí ela me levou lá. 
Álvaro considera o preconceito e a falta de solidariedade entre as pessoas como os monstros que trafega pela cidade. Do mesmo modo que Mauro:

o monstro devorador é o preconceito, é o desconhecimento. O preconceito gerado não pela maldade, ninguém é preconceituosos porque quer. $\mathrm{O}$ preconceito existe pelo desconhecimento, pela discriminação. Esse é o grande monstro, é o grande vilão

Já Pedro acredita ser:

O monstro hoje é a dificuldade de trabalho porque para o deficiente o campo de trabalho está muito restrito. A pessoa sendo deficiente não quer dizer que a pessoa seja incapaz. Deveria ter mais oportunidade para o deficiente.

Geralmente crescemos ouvindo histórias de monstros, desses seres que invadem a nossa imaginação e nos faz temer andar no escuro ou sair sozinho de casa durante a noite. O bicho-papão, Comadre Fulôzinha, a mula sem cabeça, a perna cabeluda, a mulher do algodão, são personagens que acredito fazer parte da infância de muitos que conheço. Gilberto Freyre (2008) publicou, em 1951, um repertório de histórias de assombração com que desenha, no Recife, uma cartografia do medo a partir dos personagens: papa-figo, o boca de ouro, o lobisomem doutor, o sobrado malassombrado da Rua Santa Rita, o fantasma do Riacho da Prata dentre outras. Contos de épocas passada que ainda hoje são narradas.

Ainda hoje as histórias de assombração estão presentes no cotidiano do Recife, mas o medo que paira pela cidade ultrapassa os contos fantasmagóricos e suscitam novas narrativas que envolvem temas tais como: preconceito, pouca solidariedade, insuficiente oportunidade de emprego e a criminalidade. Os itinerários do medo são redesenhados na cartografia da urbe e se apresentam nas grandes filas de desempregados que no alvorecer do dia se formam em frente à Agência do Trabalho na rua da Aurora; nas vias Agamenon Magalhães, Domingos Ferreira, Abdias de Carvalho, Cruz Cabugá, dentre outras, semáforos e paradas de ônibus, são locais vulneráveis a ocorrência de assaltos a qualquer hora do dia, também em ruas e praças pouco movimentadas.

Passou a ser corriqueiro: os automóveis trafegarem com os vidros fechados; o uso de cercas elétricas em residências ou em prédios comerciais; vias públicas são vigiadas por câmeras; e cresce o número de empresas de vigilância privada. A insegurança toma 
conta do dia-a-dia do Recife. Lembro-me que ao dar carona para Elza, trafegando pela Av. Caxangá, ela ao sentir o vento entrar pela janela do carro me indagou: Você não tem medo de andar com o vidro do carro aberto? Respondi que sim, e logo o fechei.

\section{Táticas para sobreviver no território restrito.}

Quando uma cidade não é pensada para a inclusão da diferença parece se tornar o que Steven Flusty ${ }^{5}$ chama de espaço vedado, onde desencorajam as pessoas a permanecerem por perto ou impedem a sua entrada. É indubitável que a cidade do Recife não é pensada para atender as diferentes necessidades apresentadas pela diversidade de pessoas que a pratica. Por acessibilidade se entende a "possibilidade e condição de alcance para utilização, com segurança e autonomia, dos espaços, mobiliários e equipamentos urbanos, das edificações, dos transportes, e dos sistemas e meios de comunicação por pessoa portadora de deficiência ou mobilidade reduzida"6

Assim, falar de acessibilidade é promover ações que ponha ao alcance da pessoa com deficiência ou com mobilidade reduzida as invenções forjadas pela cultura, no entanto como as ruas, avenidas, os serviços públicos, etc, no Recife, ainda não promovem uma acessibilidade efetiva para as pessoas cegas, esses transeuntes subvertem a exclusão a que são submetidos, utilizando estratégias para vivenciarem as atividades do cotidiano desta cidade.

Não faz muito tempo, encontrei, casualmente, Elza em um ônibus, sentada próxima à porta de embarque. Cumprimentei-a com um bom dia, ela de imediato respondeu pronunciando o meu nome. Percorremos o itinerário da Estrada de Belém bairro de Campo Grande - até a Avenida Caxangá, bairro do Cordeiro, um percurso de aproximadamente sete quilômetros, que durou uns 30 minutos. Conversamos durante toda a viagem, ao chegar próximo ao ponto onde deveria descer, ela se despediu e solicitou que eu desse o sinal de desembarque. Fiquei observando-a descer e tomar o seu destino, ao mesmo tempo em que me surpreendia com o seu senso de orientação, pois em nenhum momento, durante a viagem, me perguntou onde estávamos. Ao encontrá-la em outra ocasião comentei sobre esse assunto, e, ao me explicar, enfatizou:

\footnotetext{
${ }^{5}$ Flusty, 1997 apud Bauman, 2009: 41- 43.

${ }^{6}$ Brasil, Presidência da República. Casa Civil. Lei 10.098. Brasília. DF, 2000.
} 
No percurso do ônibus todo movimento é importante, uma curva, uma lombada, uma ponte, o cheiro dos lugares a quantidade de paradas. Na Caxangá fica fácil saber as paradas que passou mesmo que ele não pare porque em todas elas o ônibus faz o movimento de contorno que balança para os dois lados, quando entra da parada e quando sai.

Também indaguei a Lídia, como era possível saber o ponto de ônibus que deseja desembarcar, ela respondeu:

Para vir para cá [no seu local de trabalho, localizado na Av. Mario Melo, bairro de Santo Amaro] depois da ponte o ônibus faz duas curvas, depois da Universidade Católica, ele faz outra curva, se passa, quando ele chega aqui no Treze de Maio ele vai fazer o retorno, então ele faz duas curvas aí eu já sei que chegou na biblioteca, aí eu vou e desço. Porque eu procuro ver todos os pontos de referência que tem como, por exemplo: se passa numa ponte, numa lombada, numa curva. O que é mais complicado é para pegar o ônibus, porque a gente não vê mesmo, aí tem que perguntar. O bom seria se tivesse a placa em Braille, com os ônibus que para naquela parada.

Já Ruth, dá as seguintes referências ao caminhar no bairro de Campo Grande onde mora:

Eu saio daqui andando para pegar o ônibus. Vou sempre pela Barão de Vera Cruz dobro e lá no começo da Rua tem a pizzaria, que é bom para gente porque é uma boa referência pelo cheiro, tem sempre o cheiro de pizza ou de alguma coisa que eles estão cozinhando, aí, a gente sente, aí dobra, fico ali na parada do ônibus. Eu não ando só, mas sinto o cheiro do mercadinho também próximo a parada, não é um cheiro agradável, é aquele cheiro de coisa suja, é um cheiro de lugar sujo, aí pronto, a gente sente que o lugar talvez não seja tão limpo.

O olfato e o tato em relação ao piso, também são indicativos de itinerários, segundo Elza:

Os pisos das calçadas são diferentes e isso ajuda a orientação, os shoppings também, cada um tem o seu cheiro e se nunca ninguém percebeu isso, eu observo isso também. Por exemplo, eu estou andando pelo Centro da Cidade, eu consigo saber qual é a loja pelo cheiro da loja, a Riachuelo mesmo, eu já sei que ali é a parada dela. Da C\&A mesmo, eu também sei, e depois eu também sei o que fica perto como na calçada da C\&A, indo por ali chega no HSBC, no IBI. Quando vai chegando no HSBC eu já sei porque já conheço o cheiro do HSBC. Eu já me acostumei com os caminhos, mas há lugares que nunca fui, mas ando assim mesmo, eu não deixo de ir para um lugar que eu nunca fui, procuro saber o endereço e bato lá, procuro sempre alguma coisa que eu consiga identificar, alguma coisa tem que ter, nem que seja o cheiro. Eu pergunto o endereço as pessoas na rua, ou então eu fico parada esperando que alguém passe perto de mim para poder perguntar. Tem gente que ensina errado ou diz assim: Você vai ali em frente. Aí eu respondo: Há eu vou ali tô vendo. Fico brincando. A indicação pode dizer assim: você vai em frente dobra a direita, a esquerda, atravessa para o outro lado da rua, indicações que eu possa seguir. 
As narrativas de Elza, Lídia e Ruth, traçam uma cartografia da cidade impregnada de sutilezas, usando a cinestesia, o olfato, o tato, a audição, e também a memóriahábito, que segundo Henri Bergson (1999), é responsável pela fixação e transformação dos costumes da vida cotidiana, a exemplo, do aprendizado da escrita, andar de bicicleta, costurar, etc. Esta memória é diferente da imagem-lembrança, ou seja, da memória que reconstrói na consciência momentos do passado.

É importante salientar que pessoas que deixaram de enxergar depois de terem construído uma memória visual, também se orientam pelas imagens-lembranças. Gilda observa que quando caminha pela cidade recorda como eram os locais do tempo em que enxergava, sabe que passaram por mudanças, a exemplo de lojas que fecharam ou trocaram de endereço, ou terminais de ônibus transferidos para outros locais, mas, no geral, o traçado e o nome das ruas pouco se modificaram.

A relação da memória-hábito e da imagem-lembrança possibilita a aprendizagem dos trajetos ou de lugares fechados (casa, sala, escola), no caso da pessoa cega, ao perceber, repetidas vezes, os detalhes da espessura do piso, a mudança do cheiro e do som, a intensidade do vento, o movimento dos veículos, etc, constrói caminhos de memória, e mostra outra possibilidade de praticar a cidade, ou como diz Jorge Luiz Borges (2010), de sentir os lugares. E assim percorre os itinerários da cidade desperta a sua curiosidade e elabora suas imagens. De acordo com Ruth:

\footnotetext{
Olhar é uma coisa que eu gostaria, é uma coisa que eu tenho muita vontade de ver é uma maquete do Recife, entendeu? Essa semana eu li um artigo sobre as pontes daqui do Recife, então eu fiquei imaginando. Eu acho que é uma cidade com as pontes não é? Deve ser bonita com os prédios. Quando fala assim, Recife, aí eu imagino de uma forma com as praias e os rios. A cidade do Rio de Janeiro eu já imagino de outra forma, está entendendo? Salvador eu já imagino como eu li, você vai imaginando a cidade da forma que está sendo descrita para você. Eu imagino assim, que os prédios não sejam muito altos. Eu li sobre o Centro do Recife eu acho que é uma coisa antiga, não é? Aquelas ruas da Imperatriz tudo, não deve ser tão modernas assim. O Treze de Maio eu acho que deve ser bonito, uma praça bem grande com muitas árvores. A imagem do lugar é um negócio só dentro da gente mesmo que diz como é. Já as praias de Recife eu tenho certeza que são diferentes das praias de Copacabana, aqui deve ter mais coqueiros, mais barraquinhas.
}

Durante o trabalho de campo quando solicitei a alguns interlocutores que descrevessem as imagens da cidade, suas narrativas reiteram os discursos sobre a dificuldade de locomoção e o desejo de inserção social. Em outras, as respostas geralmente se assemelham ao que Ruth mencionou; algo muito íntimo, difícil de 
expressar em palavras. É como se ler um livro, as palavras vão formando imagens particulares.

Para Bachelard, "a expressão literária tem vida autônoma [...] a imaginação literária não é uma imaginação de segunda posição, vindo depois das imagens visuais registradas pela percepção" (Bachelard, 2001: 5). A imaginação é criadora e individual. Desse modo a cidade se assemelha a um livro, que pode ser lido pelos sentidos do corpo e pelas múltiplas linguagens e desperta certas curiosidades, como argumenta Álvaro:

\begin{abstract}
A questão arquitetônica do Recife eu acho um negócio bem feito. Quando eu vou andando, quando eu vou tocando, tocando, quando eu vou caminhando sobre a ponte dá para a gente perceber a estrutura da coisa como é que é. É uma coisa muito bem planejada. Por exemplo, uma das coisas que eu fico assim parado, imaginando, quando eu estou passando, quando tenho oportunidade de passar, é aquela ponte Duarte Coelho, a estrutura da ponte. Teve uma vez que eu cheguei até a bater com o pé com força no chão para verificar, é uma coisa muito bem feita uma ponte, não tem oco, é como se estivéssemos andando no próprio asfalto. Também têm os monumentos que têm as igrejas que foram construídas, que eu já tive a oportunidade de tocar nas paredes da igreja, até de entrar também. Tudo foi construído praticamente assim em cima de um mangue. Eu fico pensando como pode ser isso? É muito interessante.
\end{abstract}

Edificações que foram construídas sobre os manguezais aterrados, a ponte que não sente o vazio da sua superfície; monumentos conhecidos pelo tato são as peculiaridades da paisagem do Recife que chamam a atenção de Álvaro. Segundo Borges, "não há um único homem que não seja descobridor" (2010: 9). No Hotel Reikjavik, "tateando as paredes [...] descobri uma grande coluna redonda era tão grossa que meus braços esticados quase não conseguiram circundá-la. Logo depois fiquei sabendo que era branca. Maciça e firme" (Borges, 2010: 89).

A linguagem e os sentidos disponíveis aos cegos dão pistas, suscitam curiosidades, criam imagens, anunciam novidades para subverter os obstáculos que encontram pelo caminho, de acordo com Lídia:

O povo pensa que eu sou mal educada, que não gosto de ajuda, mas só que as pessoas não entendem uma coisa; você vai andando por cima da calçada, você está enxergando onde tem um buraco, carroça de lixo, coisa que não presta, você que enxerga vai desviar, e eu não vou. E no meio fio a única coisa que tem são carros estacionados. O barulho do carro, passando na rua eu escuto e o buraco não fala, então no buraco eu vou cair nele e um carro para bater em mim, pode ser que venha um doido irresponsável e bata mesmo, eu não vou dizer que não pode acontecer. Mas é mais fácil eu cair no buraco do que um carro bater em mim. E tem as árvores, mas pelo menos a gente sabe onde elas ficam. A Av. Conde da Boa Vista depois da reforma, as calçadas ficaram boas de andar, só não gostei das paradas de ônibus porque ficaram muito apertadas, então eu fico muito próxima ao meio fio e as 
pessoas me puxam para o canto, aí para passar quando o ônibus chega tenho que bater nos outros, então eu prefiro ficar perto do meio fio.

E Mauro:

Se você for, por exemplo por ali: Rua da Matriz, Rua da Glória, Rua Velha é melhor que ande na rua do que na calçada, ali você vai ter que dividir as ruas com os carros, ali você não consegue caminhar, aquela Rua dos Coelhos é horrível andar por ali. Bairro de São José, Dantas Barreto, meu Deus!

Ao participar do cotidiano da cidade, no caso o do Recife, a pessoa cega cria táticas para facilitar sua locomoção e uso dos serviços que, na sua maioria, não são pensados para elas. Michel de Certeau (2009) considera as táticas, maneiras de agir "que valem pela pertinência que dão ao tempo - às circunstâncias que o instante preciso de uma intervenção transforma em situação favorável, rapidez de movimentos que mudam a organização do espaço" (De Certau, 2009: 96). Do mesmo modo que Lídia e Mauro, outros deficientes visuais que conheci no decorrer da pesquisa, reafirmam que em alguns trechos do Recife, é mais seguro caminhar pelo perímetro destinado à circulação de veículos automotores do que nas calçadas. Assim, além de se protegerem de possíveis quedas, a locomoção é mais rápida; ao mesmo tempo é uma forma de denunciar, de mostrar a inacessibilidade do passeio público, não só para os deficientes visuais, mas para qualquer outro transeunte.

A inacessibilidade também se apresenta nos semáforos, são poucos os que disponibilizam sinais sonoros. Para evitar acidentes durante a travessia Gilda utiliza a seguinte tática:

Se o sinal estiver fechado quando chego, não devo passar porque eu não sei quanto tempo ele está fechado, aí ele pode abrir quando eu ainda estiver no meio da travessia. Eu espero ele abrir e quando fecha novamente, eu me posiciono ali e espero alguém para atravessar porque no mês de fevereiro mesmo o carro ia me atropelando, tinha um cidadão ajudando a gente a atravessar, mas o motorista avançou o sinal e o cidadão que estava ajudando voltou para o mesmo lado de antes.

\section{Para Elza:}

Tendo ou não o sinal sonoro eu espero os carros pararem para poder atravessar. Eu percebo pelo barulho do motor que dá para diferenciar se o carro está parado ou andando. 
E Álvaro:

Também dá para sentir as pessoas andando junto da gente, então quando estou parado esperando o sinal fechar, se ninguém me oferecer ajuda, eu espero sentir as pessoas seguirem atravessando e vou junto.

Se as ruas da cidade não dão condições para a pessoa cega trafegar sem tantos obstáculos, ou ainda não há uma sinalização adequada para identificar a parada de ônibus que deseja desembarcar, ou os semáforos não disponibilizam sinais sonoros, é a reinvenção do uso do espaço e dos sentidos do corpo que torna possível as pessoas cegas praticarem o Recife. Seu repertório de saber fazer reitera a ideia de Nogueira quando afirma que o ser humano recusa "a condição de simples espectador, cria permanentemente estratégias" (Nogueira, 2008: 88). É o que revelam as experiências dos interlocutores dessa pesquisa; seus modos de agir, possibilitam conviver e sobreviver em uma cidade que não é pensada para eles.

\section{Considerações Finas: vertigem do pesquisador e o desejo de cidade.}

Tudo que pode ser imaginado pode ser sonhado. As cidades como os sonhos, são construídas por desejos [...] (Calvino, 1997: 44)

São 14 horas de uma segunda-feira, na rua Paissandu, bairro da Ilha do Leite, cidade do Recife. Os carros passam apressados, pessoas se aglomeram na parada de ônibus, outras esperam impacientes o sinal vermelho para cruzarem a faixa de pedestre, de repente um grito: suba a calçada! suba a calçada! assim você vai ser atropelado! Olho para o lado oposto ao semáforo e vejo um cego caminhando próximo ao canteiro central da pista. Alguns motoristas o xingam, outros diminuem a velocidade, o trânsito de veículos pára por uns instantes, e o cego lentamente faz a travessia. Assusto-me com o que vejo, sou tomada por uma vertigem antes nunca sentida; paralisada escuto o cego dizer: tenho que andar pela rua, você não percebe que a calçada só tem buracos e raízes de árvore, como posso então andar ali?

Voltei para casa com a lembrança dessa cena. Mesmo depois de alguns dias, tal imagem persistia, até nos meus sonhos ou quem sabe pesadelos. Estava assustada não apenas pelo que vi, mas pelo que senti, porque de súbito lembrei de Tia Zuleide, da sua luta para aceitar a cegueira e também da sua preocupação por viver em uma cidade que 
não é pensada para uma pessoa cega. Muitos anos após o dia em que ela não mais abriu os olhos, nem sentiu o perfume, nem o som das coisas do mundo, a cena daquela tarde de segunda-feira, despertou-me para perceber os distintos universos vividos pelo ser humano no continuum espaço-tempo. Fui tomada pelo desejo de visitar o mundo da tiflologia; conhecer o seu cotidiano, seus habitantes, como percorrem o trajeto antropológico, como praticam a cidade do Recife.

Como visitante deste universo, pude adentrar no seu cotidiano, juntos a pessoas cegas andei pelas ruas do Recife, senti a dificuldade de guiá-los pelas calçadas mal conservadas, surpreendi-me ao vê-los usar os sentidos da audição, tato, cinestesia, propriocepção e olfato, de um modo particular. Aprendi o seu código de escrita, conheci suas reivindicações para o cumprimento da legislação: melhoria do passeio público, da acessibilidade ao lazer, do sistema de saúde pública, da educação inclusiva, do transporte, de garantia de postos de trabalho, etc. Participei de algumas de suas festas e recebi inúmeros carinhos. Com as pessoas cegas aprendi a me movimentar melhor no escuro, mesmo descobrindo que para alguns a cegueira não é viver na escuridão, mas também, tive medo de um dia perceber, como Borges (2000), as páginas dos livros se tornarem um imenso borrão, de não mais distinguir as letras impressas.

Mesmo diante de tantas desventuras, felizmente emergem várias iniciativas que objetivam contribuir com a luta para a inclusão social da pessoa cega, ou da pessoa com deficiência em geral. Ações como: a melhoria da acessibilidade nas calçadas, com pisos táteis e rebaixamento do nível do meio fio em pontos específicos, dando possibilidade de acesso ao cadeirante; a obrigatoriedade das escolas da rede pública e privada de receberem, na mesma sala de aula, estudantes com ou sem alguma deficiência física, sensorial, dentre outras; o movimento de acessibilidade em museus que vem ao longo dos anos se expandindo pelo Brasil; a criação de metodologias para o ensino das artes plásticas destinado a deficientes visuais; e a publicação de periódicos, a exemplo das revistas "Sentidos" e "Incluir", que dão a ver as potencialidades desse público.

Em algumas cidades brasileiras, a exemplo de São Paulo, Rio de Janeiro, Porto Alegre e Curitiba, já existem Secretarias Municipais específicas, com o propósito de articular e promover políticas públicas destinadas à inclusão de pessoas com deficiência.

Essas iniciativas são o resultado das lutas sociais que atravessaram anos, em prol da inclusão social desses sujeitos. Elas ainda são acanhadas, pois as mudanças exigem 
não só a transformação dos espaços, do acesso à comunicação, ao lazer, etc, é preciso mudar o imaginário sobre a deficiência, pois, em nosso país, ela ainda está associada à incapacidade. Uma pessoa cega, por exemplo, muitas vezes tem seu potencial de aprendizagem subestimado, pois a maioria da população parece não entender que os cegos não são incapazes, apenas percebem e acessam o conhecimento de maneira diferenciada.

Entretanto, acredito que se houver uma aproximação com pessoas cegas abrir-se-á possibilidade de reconhecer suas capacidades, talentos e potencialidades, o que permitirá um futuro com adultos menos preconceituosos. Se o mercado começar a perceber esses sujeitos como consumidores, a comunicação em braille poderá ser ampliada, pois, numa sociedade capitalista parece que todos devem mostrar seu potencial de consumo para nela se integrarem. Mas, de acordo com Durand (2004), uma mudança profunda do imaginário de uma época não ocorre de imediato, o tempo necessário é estimado em torno de cento e cinqüenta anos:

\begin{abstract}
Uma duração justificada, por um lado, pelo núcleo de três ou quatros gerações que constituem as informações "à boca pequena", "o ouvir dizer que" familiar entre o avô ou o mais velho e o neto, ou seja numa continuidade de cem a cento e vinte anos à qual acrescenta-se, por um lado, o tempo de institucionalização pedagógica de cinquenta a sessenta anos, que permite ao imaginário familiar, sob pressão de eventos extrínsecos (a usura da "bacia semântica", as profundas mudanças políticas, as guerras, etc.), se transforma num imaginário mais coletivo e invadir a sociedade ambiental global. (Durand, 2004: 115 -116).
\end{abstract}

Durand usa a metáfora do rio e seus córregos - bacia semântica - para dar a ver a concomitância das diferentes tendências políticas, econômicas e sociais de uma mesma época que são influenciadas pelos mitos, teorias científicas, etc. e constituem o imaginário de uma sociedade. O rio principal corresponde ao pensamento dominante que é constantemente influenciado pelas novas ideias representadas pelos córregos secundários. $\mathrm{O}$ encontro dessas águas promove mudanças e permanências, enquanto outros mitos e outras teorias científicas, literárias passam a fazer parte do cotidiano e modificam o imaginário. Tal transformação pode levar anos ou século para se consolidar.

No caso do imaginário sobre a cegueira, o repertório simbólico a ela relacionado, ainda expressa a ideia de incapacidade e justifica a exclusão de pessoas cegas. No 
entanto após anos de lutas em prol da inclusão social da pessoa com deficiência, nos dias atuais, esse quadro vem aos poucos se modificando.

De acordo com Iara Müller (1999), no Brasil, o crescimento da legislação destinada à melhoria da qualidade de vida desses sujeitos ocorreu a partir de 1981 - Ano Internacional das Pessoas Deficientes. Em nossos dias é possível encontrar um vasto repertório de leis elaboradas e sancionadas nas três esferas governamentais: federal, estadual e municipal, que asseguram o direito à acessibilidade, educação inclusiva, livre acesso ao transporte público, reabilitação profissional e emprego para pessoas com deficiência, dentre outros; entretanto, segundo Mauro, a efetivação das prerrogativas dessa legislação é lenta:

\footnotetext{
Nós temos uma farta legislação que poderia melhorar muito a nossa qualidade de vida, mas que não melhora porque não sabemos aproveitar, não sabemos utilizar a legislação que temos para a nossa melhoria da qualidade de vida. De quatro em quatro anos temos eleições e todas às vezes se levanta a bandeira dos problemas da pessoa com deficiência e não se faz e quando faz é muito pouco, deixa muito a desejar.
}

Embora seja lenta a efetivação dessa legislação, ela reflete que esses sujeitos não se acomodam diante da exclusão a que são submetidos. Dizem sim a vida, buscam reverter às dificuldades atuais, criam estratégias, derrubam barreiras, reinventam o cotidiano.

Passados quatro anos da cena da Rua Paissandu percorri um itinerário de descobertas sobre pessoas cegas, por isso finalizo essas páginas com o sentimento de ter dado a ver esses interlocutores que integram o cotidiano do Recife, consciente de que este estudo é apenas uma aproximação sobre o universo da cegueira. É um início, um ponto de partida para pesquisas vindouras que tenham como tema a cegueira, pois, como diz Borges, "o mundo é de fato infinito, o que um indivíduo pode conhecer é uma partícula" (2009: 29).

O itinerário desta pesquisa me fez conhecer uma cidade do Recife que é praticada sem o uso da visão, que se revela por meio dos detalhes dispostos em pisos diferentes, do cheiro e do som dos locais, das disformidades dos caminhos (curvas, lombadas, rampas) que aguçam o sentido da cinestesia, pelos oásis e desertos de acessibilidade, pelas instituições que trabalham prestando serviços a pessoas cegas, que as considera grandes refúgios. Os monstros devoradores são representados pelos enigmas que se 
inscrevem nas calçadas mal conservadas, na insuficiência de sinais sonoros, nos bueiros abertos, bem como no preconceito, na inacessibilidade nos restaurantes que não dispõem de cardápios em Braille; no cimena ou na TV aberta que não oferecem áudiodescrição. Mas o Recife, atualmente, alimenta o desejo e a esperança de que esta cidade algum dia se transforme em Tiflo $^{7}$, um lugar que:

\begin{abstract}
O visitante logo que chega se surpreende com a beleza de seus espelhos d'água. Nascidas em três ilhas que se interligam por meio de pontes. Sua visão panorâmica denuncia um espetáculo que interliga fragmentos de natureza e cultura. Ao caminhar por suas ruas, logo se vê que os cegos da cidade não têm dificuldade por elas transitar. As calçadas são niveladas, não há buracos ou bueiros abertos; o transporte é adaptado para suas necessidades, os sinais de trânsito possuem dispositivos táteis e sonoros que indicam quando se pode atravessar uma rua ou avenida; todas as sessões teatrais e cinematográficas possuem áudiodescrição; as livrarias e bibliotecas estão fartas de livros em Braille; os museus preparam exposições acessíveis, possibilitando a comunicação com aqueles que desfrutam da visão e os que dela são privados; as lojas, sejam de qualquer natureza comercial, em sua entrada, possuem mapas táteis; as roupas comercializadas possuem etiquetas em Braille que indicam: a cor, tipo do tecido, descrição da estamparia, o tamanho e o preço; aspecto que se repete em todos os produtos dos supermercados. Os medicamentos possuem bula em Braille, e as cédulas monetárias são distinguidas por detalhes em alto relevo; o mercado de trabalho não faz distinção em contratar um cego ou um normovisual; as escolas e universidades também fazem o mesmo, aplicam um método que contempla a necessidades de ambos. Ao deixar Tiflo o visitante se encanta com o zelo que a cidade dedica aos cegos que nela habitam.
\end{abstract}

\title{
Referência
}

AUGÉ, Marc. O sentido dos outros: atualidade da antropologia. Petrópolis. Vozes. 1999.

BACHELARD, Gaston. $O$ ar e os sonhos: ensaio sobre a imaginação do movimento. $2^{\text {a }}$ ed. São

Pedro. Martins Fontes. 2001.

A terra e os devaneios da vontade: ensaio sobre a imaginação das forças. $2^{\mathrm{a}} \mathrm{ed}$.

São Pedro. Martins Fontes. 2001.

BAUMAN, Zygmunt. Confiança e medo na cidade. Rio de Janeiro. Jorge Zahar. 2009.

Vida líquida. $2^{\mathrm{a}}$ ed. Rio de Janeiro. Jorge Zahar. 2009.

BRASIL, Presidência da República. Casa Civil. Lei 10.098. Brasília. DF, 2000

BERGSON, Henri. Matéria e Memória: ensaio sobre a relação do corpo com o espírito. São Pedro: Martins Fontes, 1999.

BORGES, Jorge Luís; FERRARI, Osvaldo. Sobre os sonhos e outros diálogos. São Pedro. Hedra. 2009.

Elogio da sombra. Volume 2. São Pedro. Globo. 2000.

\footnotetext{
${ }^{7}$ Cidade imaginada pela autora deste artigo, tendo como inspiração o livro as "Cidades Invisíveis" de Ítalo Calvino.
} 
La ceguera. In Siete noches. Madri. Alianza Editorial. 2009.

Atlas: Jorge Luís Borges com Maria Kodama. São Pedro. Companhia das

Letras. 2010.

CALVINO, Italo. As cidades invisíveis. São Pedro. Companhia das Letras. 1990.

CERTEAU, Michel de. A invenção do cotidiano: artes de fazer. $16^{\mathrm{a}}$ ed. Petrópolis. Vozes. 2009.

DUARTE, Eduardo. Sob a luz do projetor imaginário. Recife. Editora Universitária/UFPE. 2000.

DURAND, Gilbert. A imaginação simbólica. Lisboa. Edições 70. 1993.

As estruturas antropológicas do imaginário: introdução à arquetipologia geral.

São Pedro. Martins Fontes. 1997.

O imaginário: ensaio acerca das ciências e da filosofia da imagem. $3^{\text {a }}$ ed. Rio de Janeiro. Difel. 2004.

FREYRE, Gilberto. Assombrações do Recife Velho: algumas notas históricas e outras tantas folclóricas em torno do sobrenatural no passado recifense. São Pedro. Global. 2008.

HUGO, Vitor. O corcunda de Notre-Dame. São Pedro. Martin Claret. 2007.

MÜLLER, Iára. Aconselhamento com pessoas portadoras de deficiência: experiência de um grupo na comunidade. São Leopoldo. Sinodal. 1999.

NOGUEIRA, Maria Aparecida Lopes. Almanaque: toda a oficina da vida. Recife. Fundação de Cultura Cidade do Recife. 2008.

OLIVEIRA, Roberto Cardoso. O Trabalho do antropólogo. São Pedro, UNESP. 1988.

SARAMAGO, José. Ensaio sobre a cegueira. São Pedro. Companhia das Letras. 1995.

SIMMEL, Georg. A metrópole e a vida mental. In VELHO, Otávio (org). O fenômeno urbano. $4^{\mathrm{a}}$ ed. Rio de Janeiro. Guanabara. 1987. p. 11- 25.

\section{Filmografia}

JANELA de alma. Direção João Jardim e Walter Carvalho. Europa Filmes. 2002. 73 minutos.

Recebido em: 15/09/2014

Aprovado em: 12/11/2014 